\title{
INSURGENCY AND PEACE BUILDING IN THE NORTH EAST INDIAN STATE OF MANIPUR
}

India has been in the news a lot recently due to its consistent impressive economic growth rate since the nineties and also because of the 2014 elections. Being the world's largest democracy, and having performed well economically over the past couple of decades, India has received considerable attention from the western media and in academia. However, one area which does not seem to get much attention is the on-going insurgency in the remote Indian northeast. In the area of security studies, western academic research tends to focus on conflicts in the Middle East and SubSaharan Africa without paying sufficient attention to on-going conflicts in contemporary Asia. The conflict in the Indian northeast is a conflict which most people in the west are not familiar with. Not much is known about this insurgency because of its geographical isolation and remote location in the eastern sector of the Himalayan mountain range in South Asia. The Indian northeast is culturally diverse and is home to a large number of India's religious and racial minority communities. The region is home to many tribal groups, ethnic and religious minorities such as the Naga Christian community in Nagaland. India calls itself a secular democracy. One of the hallmarks of a democracy is how the state secures the rights of minority citizens. In a democracy it is the responsibility of the ethnic majority to maintain positive relations with ethnic minorities. Since the 2014 elections with the arrival of the Modi government which has strong links with Hindu nationalist groups, attacks on religious minorities have been on the rise. Rajeev Bhargava writes, 'since the ominous growth of militant Hindu nationalism and the consequent alienation of religious minorities, only someone with blinkered vision would deny the crisis of secularism in India today. ${ }^{i}$

It is the aim of this paper to look at the situation in north eastern India and to focus more specifically on the state of Manipur. The research question that this paper asks is: What are the different facets of the conflict in the Indian northeast? The paper argues that the conflict in the Indian northeast is most certainly a complex one and is multifaceted. Some of the facets of the conflict, which this paper identifies, include poverty and unemployment, poor governance, administrative failure, criminality, political instability through strikes, extortion by insurgent groups, corruption, draconian laws such as the Armed Forces Special Powers Act, human rights abuses caused primarily by the Indian military and active forces of secession. These are some of the ills which have plagued the northeast for more than five decades. The primary data which has been collected for purposes of this paper supports this line of argument. In terms of primary data, the paper takes a bottom up approach and there is an emphasis on the voices or ordinary people of Manipuri descent. The paper makes a shift from the traditional top down approach where the emphasis has been on the voices of the political elite and decision makers. The paper is also interested in methods of peace building and conflict management. After a discussion of the situation in the Indian northeast and then Manipur, the paper suggests methods of peace building as the way forward right at the end of the paper. 


\section{TRYING TO MAKE SENSE OF CONFLICTS IN THE INDIAN NORTHEAST: THE THEORETICAL BACKGROUND}

Before we go into the details of the conflict in the Indian northeast, it is firstly important to have some understanding of the theoretical background. What are the sorts of theories that can help us understand the on-going insurgency in the Indian northeast? The conflict in the Indian northeast is so complex that it is difficult to put it in a box and categorise it and put a label on it. The conflict in the Indian northeast is in constant motion and is changing all the time. It is in a state of flux which makes it even more difficult to put a single label on it. The conflict is multidimensional and fluid and subject to change. The conflict has changed its colour and identity with time. For instance, the way the conflict existed in the immediate post 1947 period is very different to the way the conflict exists today. The insurgency is partly associated with secessionist nationalism, it is partly an ethnic conflict, and partly it is a civil war. Not one theory will be sufficient to capture the insurgency in the Indian northeast in its entirety. Therefore, it becomes necessary to analyse multiple theories and take them up collectively for discussion. We will be able to get a nuanced understanding of the conflict only if we take these theories up collectively for discussion. By taking multiple theories collectively or more correctly different aspects of these theories collectively, will we get a good understanding of the situation in north eastern India. In this context mention maybe made of the nationalism thesis and the theories associated with ethnic conflict and civil war. It is these theories which throw considerable light on the complex situation in the Indian northeast. In other words, there are elements of the nationalism thesis, elements of the ethnic conflict thesis and elements of the civil war thesis all co-existing in the conflict in the Indian northeast. Let us first start with the nationalism thesis.

\section{THE NATIONALISM THESIS:}

Nationalism pervades the modern world and although most analysts see it as a recent phenomenon, the beginnings of nationalism can never really be known to us. Its origins are clouded in mystery and confusion. "Nationalism is the desire amongst a community or people who believe that they share a common ancestry and a common destiny to live under their own government on territory or land that is sacred and central to their history. ${ }^{\text {iii }}$ Nationalism cannot be conceived without the state and vice versa." Nationalism equals a nation plus feelings of patriotism. A nationalist argument is based upon three assertions, that there exists a nation with distinct characteristic features, and that the interests and values of this nation must take priority over all other values and interests, and finally the nation must be as independent as possible. ${ }^{v}$ There are different constituents or ingredients which bring a community together and strengthen a sense of community-ness. These ingredients include a common language, a common culture, geographical proximity, a common race, common ethnicity, a common religion, common economic interests and common political aspirations. Territorial borders play the role of boundaries of social membership

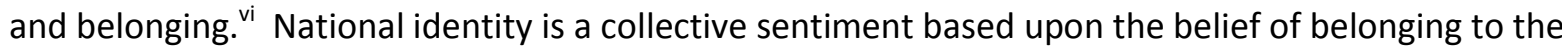
same nation and of sharing most attributes that make the nation different from other groups and nations. ${ }^{\text {vii }}$ Belief in common culture, history, kinship, language, religion, territory, founding moment and destiny have been invoked with varying intensity by groups claiming to share a particular national identity. ${ }^{\text {viii }}$ Ordinarily, national identity is associated with citizens of a particular nation state. However, distinct national identities may be attributed to or shared by individuals belonging to nations without states such as minority groups in north east India. 'Collective memories of a time 
when the nation was independent, endured oppression or attained international leadership tend to strengthen a sense of common identity among those who belong to the nation, even if it lacks a state of its own' ${ }^{\text {ix }}$ This is very much the case with the Naga community in Nagaland and also with the tribal groups in Manipur in the Indian northeast. It has been argued that communities in the Indian northeast do not see themselves as Indian but as a distinct nation in their own right. For instance, the Naga's have often argued that they are not Indian by choice but Indian by force. Instead of sharing a sense of one-ness with mainstream Indians living in India proper, many in the Indian northeast share a sense of one ness and identification with their ethnic brothers across the international border in the Kachin state in northern Burma which has a direct/common border with India's north east. Sajal Nag writes, 'the Naga demand for independence was backed by an organised campaign which legitimised their aspiration for a sovereign homeland based on their ethnicity and history'. ${ }^{x}$ This is why security analysts like Kanti Bajpai strongly associate problems in the Indian

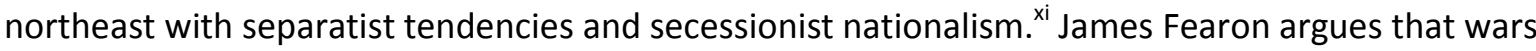
associated with separatist nationalism cause considerable loss of life, a refugee crisis, damage to property and the economy more generally, and 'strains on great power relations' ${ }^{\text {xil }}$

Nationalism is a major factor and force in the contemporary world especially amongst those people who have won their independence recently from colonial rule. It is also a strong force amongst those who are still struggling to achieve political, social and economic justice. In the area of domestic affairs, states are facing the challenge of separate identification of nationality and nation from its inhabitants. Out of all the groups in the Indian northeast, the Naga's have been the most vocal in calling themselves a distinct nation. The Naga conflict is one of the oldest conflicts in north eastern India. India has had to deal with Naga separatism and recalcitrant Naga groups' right from 1947 till recent times. Needless to say this has caused much violence. 'Nationalism becomes destructive when its exponents convince themselves that they hold the key to doing away with the existential tensions that lie at its heart, rather than accepting and embracing its paradoxical qualities. Innumerable atrocities and crimes against humanity have been committed in the name of simplistic and one sided visions of nationalism. ${ }^{\text {xiii }}$ Ethnic and nationalist violence tends to appear in two forms argues Adeel Khan: It is directed either by the state or for the state. ${ }^{\text {iv }}$ The state sees any voice of dissent and any demand for autonomy or self-determination as 'provincial', 'tribal', and most certainly disruptive. The state often feels the need to suppress this voice of dissent. On the other hand, ethnic, racial, religious and linguistic minorities feel marginalised and see the state as not their own but as an enemy, who is hostile to their interests. Therefore, they struggle to make the state either more responsive to their demands and needs or if that is not possible or if their attempts fail in doing so, it becomes almost necessary to create their own state. ${ }^{\mathrm{xv}}$ The nationalism thesis has considerable explanatory power and gives us some insight into the conflicts of the Indian northeast. In other words, the nationalism thesis can be applied to the Indian northeast to a large extent. The word, 'nation', can sometimes be very confusing and often means a people with a common ethnic origin. The problem often arises when sometimes the boundaries of nations/peoples do not coincide with those of the state. In this connection, some scholars may use the term ethnonationalism which is also helpful in understanding the situation in north eastern India.

\section{CIVIL WARS AND ETHNIC CONFLICTS AS AN EXPLANATION:}

A more straight forward way of looking at these conflicts is just seeing them as civil wars or internal wars and as ethnic conflicts. A civil war is very complex social phenomenon with many inter 
related and overlapping dimensions. 'Civil wars are actor oriented. A given society or state may have deep inherited fault lines capable of destabilising it, but it can only rupture in the event of an intervention by a particular individual, group or regime'. xvi One of the main causes of civil wars, Misra argues, is grievance and relative deprivation. This is very much the case with disgruntled groups in north eastern India. As mentioned earlier in the opening lines of this paper, there has been much talk in the West about India's impressive economic growth rate in recent years but this growth has not been uniform. Not all parts of India have benefitted from India's economic success uniformly. Some parts of the country have benefitted more than others. The northeast is one part of the country which has not benefitted at all and there has been no trickle-down effect either. To make matters worse, the central government in New Delhi has often tried to exploit north eastern resources like oil to suit the needs of people living in the heartland or India proper. The Indian northeast is one of the most under developed and impoverished parts of the country. Civil wars are the ultimate manifestations of the collective grievance of a people. Thus, various factors which have caused civil wars in the past include economic inequality, political oppression and fierce competition over scarce resources. These wars are often associated with armed conflicts which involve the military and military action, active participation of the central government and the resistance from both sides. All of these features of civil wars can be found in the conflict or conflicts in the Indian northeast. Bethany Lacina is of the view that civil wars tend to take place in weak states where insurgents tend to have easy access to aids, which then help them to carry out a rebellion. ${ }^{\text {xvii }}$

Related to the term, 'civil war', is the term 'ethnic conflict'. Some analysts believe that long drawn protracted conflicts over the rights and demands of ethnic and religious groups have caused much more misery, havoc and loss of life than has any other type of local, regional and international conflict since the year 1945. ${ }^{\text {xiii }}$ Traditionally, ethnicity has been defined in terms of shared genetic, racial and sometimes linguistic traits amongst people or a community, usually visibly apparent and hence easily detected by outsiders. ${ }^{\text {xix }}$ It can be associated with a type of cultural segmentation which also interacts with class. Ethnicity seems to be a new term although the word, 'ethnic' is much older and is derived from the Greek word, 'ethnos' ${ }^{x x}$ Like nationalism, ethnic groups and their associated ideologies stress the cultural similarity of their supporters and thus begin to draw a strict line of demarcation and boundary vis a vis others who thereby become or are seen as outsiders. ${ }^{x x}$ The Naga construction of the self vis a vis mainstream Indians was essentially based on the principle of othering. ${ }^{\text {xii }}$ Naga's are from a distinct racial stock, they have a distinct social life, manner of living, laws and customs and even their method of governance of people is quite different from India proper, and finally from a religious standpoint the great majority of Naga's are animists, but Christianity which was introduced by the American Baptists long before the advent of British rule has been on the rise in recent times. ${ }^{\text {xiii }}$ Bhagat Oinam adds to this and writes, 'collective consciousness has emerged among tribes in the region through formation of separate political identities. ${ }^{\text {'xiv }}$ In nonwestern societies particularly in the global south, ethnicity has had a much more profound and direct impact on the creation of nations. ${ }^{x \times v}$ Imperialism and colonialism drew the boundaries of new states in Asia and Africa without much regard for ethnic identities, yet also encouraged the ethnic classification of populations and required some ethnic groups to play specific roles in the colonial administration and political system. ${ }^{\text {xxi }}$ This was very much the case when the British ruled India in the $19^{\text {th }}$ and $20^{\text {th }}$ centuries. Many Naga leaders have argued that they became a part of India primarily through the British conquests, but now that the British have left, they should also get their independence. 
Ethnic conflicts can often be based on ancient hatreds between the groups fighting in them. This line of argument applies to the Indian northeast because there are different tribal groups fighting one another. There are multiple layers of conflict here. For instance, the Naga community have been in conflict with neighbouring Manipuri's because the former has tried to bring all Naga people into one administrative unit including Naga people residing in Manipur. Naga's have laid irredentist claims on Manipuri territory thus paving the way for violence. The situation causes instability and paves the way for organised crime and cross border terrorism to take place and may cause other conflicts within the domestic boundaries of that country or elsewhere in that particular region. ${ }^{\text {xxvii }}$ This line of argument also applies to the Indian northeast because Naga or Manipuri insurgent groups have often received arms, weapons, and ammunition from neighbouring countries like China and Myanmar with whom they share more of a sense of one-ness. This has led to cross border terrorism, cross border interaction and the arms trade. The combination of creed, greed, and grievances exacerbated by poor leadership, vested interests, and spill over effects from conflicts in neighbouring countries relates to ethnic conflict worldwide. ${ }^{\text {xviii }}$ Discrimination, social exclusion, the persistent violation of human rights and deliberate economic and social neglect on the one hand and the ability of the leaders of the disaffected communities to capitalise on their resulting grievances appeal to their ethnic distinctiveness. This explains the situation in the north east to a large extent.

Ethnic conflict is a dispute about important social, political, economic, cultural and territorial issues between two or more ethnic communities. ${ }^{x \times i x}$ One of the first prerequisites for an ethnic conflict is that two or more ethnic groups must reside in close geographical proximity. This applies to the Naga insurgent groups who lay irredentist claims on neighbouring Manipuri territory. Naga insurgents have a political ideology called Nagalim or Greater Nagaland by which they aim to bring Naga's living elsewhere in India (e.g. Assam, Manipur and Arunachal Pradesh) and across the international border in Myanmar into one administrative unit. Naga irredentist claims on Manipur have paved the way for further conflict. Even today, if one travels to northern Manipur to a place like Ukhrul, one gets the feeling that one is in Nagaland rather than Manipur because of the Naga settlements there ${ }^{x x x}$. The Naga community has most certainly colonised parts of northern Manipur. There is a strong Naga presence in Ukhrul, although Ukhrul is very much a part of Manipur. The Naga community seems to have taken over much of north Manipur especially places like Ukhrul since they consider it to be a part of their own Naga territory. Bimol Akoijam writes, 'with a sizeable people from the hills of Manipur involved in the struggle for independence of the Nagas, the idea of a Naga nation comes into obvious confrontation with the idea of Manipuri identity'. xxi $^{\prime}$

According to Shimray, language, especially tribal Language is a major feature of ethnic identity, and the decline of tribal language often symbolises the subjugation of that particular community. ${ }^{\text {xxii }}$ When we take a closer look at the situation in north eastern India we see how many tribal people have felt threatened because of the incoming migrants from Bangladesh, which is paving the way for a Bengali preponderance in the region. The migration is undermining tribal identity and language which is why some tribal leaders have called for cultural safeguards e.g. protection of the Kok Borok language and the use of the Kok Borok language in schools in Tripura, which is one of the smaller north eastern states. .xxiii Manipuri's too were angered by the fact that their Manipuri language did not get official status until much later.

Kipgen writes, 'in an ethnically sensitive society, problems of ethnic tensions may develop intentionally or unintentionally'. ${ }^{\text {xxiv }}$ Many of these conflicts may start out as a domestic problem, 
but may snowball into an interstate war depending on the nature and intensity of the conflict and this may drag outside powers into the conflict. This has happened on one occasion in relation to the Indian northeast when the Sino-Indian War was fought in 1962. Much of the war was fought in the Indian northeast especially in Arunachal Pradesh. The Chinese and Burmese share a sense of ethnic commonality with the people in the northeast, and have been active in supporting north eastern insurgent groups with weapons. This has also paved the way for smuggling of arms, the arms trade and the black market in the region. Myanmar and India have not gone to war yet. Although an internal dispute may degenerate into a general conflagration or into a total war, this has not happened so much with regard to the Indian northeast. And although the Chinese defeated the Indians in 1962, other than helping insurgent groups in India, the China had other reasons for going to war with India. For instance, the Chinese regard Arunachal Pradesh in the Indian northeast to be a part of Chinese territory and call it 'South Tibet', and do not see it as a part of India. The boundary dispute between India and China still hasn't been fully resolved. External and neighbouring countries may also become involved in these conflicts because the troubles associated with the ethnic conflict may spill over into neighbouring countries which may add to the problem and cause further instability e.g. a refugee problem. Neighbouring countries may also intervene in internal ethnic disputes to protect the interests of their ethnic brethren. ${ }^{x \times x}$ This is of course a feature of the north east which we have already discussed. The involvement of countries like Myanmar and China in the Indian northeast is mainly to help their ethnic brothers against what is perceived as Indian oppression. Myanmar and China have provided these insurgent groups with arms, weapons, financial assistance and also training.

In many cases, ethnic groups will not be able to agree on new constitutional agreements or a peaceful separation. ${ }^{x \times v i}$ Minority ethnic groups may want to secede and establish an independent state of its own, which is a feature that we see very much happening with the Naga community and Manipuri's. Secession is a special kind of territorial separatism involving states, in which there is an abrupt unilateral move to independence on the part of a region that is a metropolitan territory of a sovereign independent state. ${ }^{\text {xxvii }}$ Ethno nationalism might be a part of the whole process of the conflict.

Ethnic conflicts are here to stay. ${ }^{\text {xxviii }}$ The minority at risk survey shows that $80 \%$ of the politically ethnic groups in the 90's were disadvantaged because of historical or contemporary discrimination. ${ }^{\text {xxix }}$ Ethnic groups that are treated unequally resent this and usually make an effort to improve their situation. The recent cases of racism and racial attacks on northeast Indian students in places like New Delhi are well known. ${ }^{x l}$ When north eastern students come to India proper for purposes of education and employment, they often face racial discrimination. In a range of interviews that I carried out recently, it became clear from the responses that many such people had been subjected to racial attacks, social exclusion and economic marginalisation. ${ }^{x i}$ Mainstream Indians often view people from the north east as backward and uncivilised. North east Indians are often called, 'Chinki', which many find very offensive, equivalent to the word, 'paki' in England which is normally directed at anyone who is of south Asian descent. The term, 'chinki', has links with the term, 'chinese' or Chinese looking. Most north eastern people are racially from a mongoloid background so Indians living in India proper often mistake them for being east Asian as opposed to south Asian. Racism and prejudice directed at the people of the north east is very much entrenched in contemporary India. 


\section{THE 'NEW WARS' THESIS:}

Another theory which helps us to understand the situation in the Indian northeast is Mary Kaldor's, 'New Wars' thesis. When Kaldor talks about contemporary conflicts she argues that there are certain features which stand out and it is these features which differentiate them from old wars or the classical definition of warfare. Some of these features include pronounced identity politics, human rights abuses, strong presence of the paramilitary, and that these new conflicts take place within the context of criminality, corruption and administrative failure. Kaldor further argues that contemporary conflicts take place in a context of pre modernity, modernity and post modernity and in a context where the state authority or the political legitimacy of the mother country is being eroded. And finally Kaldor argues that although these new set of conflicts might seem localised and confined to a particular territory, the participants of these conflicts actually have strong transnational connections.

Now when we look at the conflict in the Indian northeast, we find some of these features of the 'New Wars' thesis here. Although the conflict in the Indian northeast is not new in the sense it is not a post-Cold War conflict since it had its beginnings in pre Cold War times, it can been seen as a 'new War' in the sense that the levels of violence has escalated more than ever in the post 90's phase and that the conflict has increasingly gone on to acquire new war features. For instance, there is a strong presence of paramilitary forces like the Border Security Force, the Central Reserve Police Force and the Assam Rifles. We see gross human rights violations here in the Indian northeast (particularly the raping of women and children)caused by both the Indian Army and paramilitary forces and the insurgent groups. The conflict is most certainly associated with identity politics because one of the main issues here has been the migration from neighbouring Bangladesh which is undermining the tribal identity and the mongoloid ethos of north east India which the local people want to preserve. The conflict takes place in a context of poor governance, high levels of corruption, criminality, and administrative failure. Insurgent groups are often associated with acts of robbery. The conflict also takes place in a context where the state authority of the mother country India is being eroded since the conflict is very strongly associated with centrifugal tendencies and secessionist movements. The conflict takes place in a context of pre modernity, modernity and post modernity in the sense that when one travels to a place like Nagaland it is almost like living in the dark ages, in medieval times due to the lack of very basic infrastructure and yet not far away from Nagaland in the Indian northeast is the city of Kolkata, once the capital of British India, now the gateway to the northeast where one can see wonderful infrastructure almost similar to first world countries. And finally, although at a superficial level it may seem that the conflict is taking place within the confines of northeast India, there are strong international connections with rebel groups from across the international border in Myanmar, China, Bangladesh, Nepal and Pakistan. Thus, the 'new wars' thesis has considerable explanatory power and gives us some insight into this conflict.

We have now looked at theories associated with nationalism, new wars, ethnic conflict and civil wars, all of which can be used to understand the situation in the Indian northeast. As mentioned earlier, elements of all these theories can be found in the on-going militancy of the Indian northeast. The conflict or set of conflicts in this part of India is partly a civil war, partly a new war, partly a secessionist nationalist movement or movements and partly an ethnic conflict. It is difficult to put a single label on it especially when the insurgency is so many things all at the same time. It would be fair to say that all these conflicts are very complex and have multiple dimensions and are multi 
layered and multifaceted. These conflicts have been going on for a while now and thus have been caused by a large number of actors and multiplicity of events. Therefore, one single theory or explanation will not be enough to capture the conflict in its entirety. It thus becomes important and necessary to look at a range of theories or explanations and their different strands and combine these different strands and use them collectively to understand the complexities and political dynamics of the Indian northeast. Certain facets of these explanations will help us to understand certain aspects of the conflict and other facets of the theories will help us to understand other aspects of the conflict. Only a set of arguments taken collectively, will give us a nuanced analysis of the situation in the Indian northeast. Thus, the conflict in the Indian northeast is a secessionist nationalist movement, a new war, an ethnic conflict and a civil war, all at the same time. There are elements of the nationalism thesis, the new wars thesis, the civil wars thesis and the ethnic conflict thesis found in this conflict. All these different theoretical elements can be found in this conflict where they coexist.

\section{THE BACKGROUND: SETTING THE CONTEXT}

The imperialists associated with the British colonial administration were the first people to come up with the idea of a 'north eastern frontier', after they had colonised the Brahmaputra valley and the surrounding hill areas along the Indo-Burmese border. ${ }^{\text {xli }}$ The Brahmaputra valley was incorporated into the British East India Company's holdings in 1826 through war with Burma. ${ }^{\text {xiii }}$ The northeast is geographically very isolated and cut off from India proper. ${ }^{\text {xliv }}$ The narrow strip of land which connects the region to the rest of India is called the Chicken's Neck or the Siliguri Corridor ${ }^{\mathrm{xlv}}$. The seven states or sister states as they are often called encompass Arunachal Pradesh, Assam, Meghalaya, Tripura, Manipur, Nagaland and Mizoram. Now of course, Sikkim has been added to the list, although it is not a part of the northeast proper. Ethnically, the region is very complex. The region is sandwiched in between South Asia proper and East Asia proper, and hence culturally the region is a syncretic fusion of both south Asian and east Asian cultures. When one travels to the region, especially if one is visiting the region for the first time, one can get easily confused and may think of being in South East Asia, and not in India, since the local people tend to look more east Asian and not so much south Asian. Because of the historical migrations which have taken place from different parts of East Asia to this part of India, racially and ethnically, the indigenous people are from a mongoloid background. Geographically, the region is hilly, and the area is landlocked. ${ }^{\text {xlvi }}$ Economically, the area is impoverished. ${ }^{\text {xlii }}$ From a political standpoint, the Indian northeast has faced instability since India became independent from British colonial rule in 1947. 'Today, insurgency and political extremism have become the order of the day in north east India'. xviii $^{\text {The }}$ Indian northeast has been classified as a 'disturbed' area by the New Delhi security establishment due to the on-going insurgency and the region is subjected to the Armed Forces Special Powers Act, which is an act that gives security personnel extraordinary powers to deal with the emergency situation, the political turmoil and with underground elements. ${ }^{\text {xlix }}$ It should be noted though that the fighting happens sporadically.' The insurgency is highly fragmented and is characterised by factional rivalry. ${ }^{l i}$ This makes the situation even more complicated. The entire northeast is heavily militarised especially the states of Assam, Nagaland and Manipur where the levels of violence are at its peak. The region is heavily militarised with different sections of the Indian Army and other paramilitary forces. The paramilitary forces include the Border Security Force, the Central Reserve Police Force 
and the Assam Rifles. Because of such a heavy military presence, police brutality is common. Police atrocities and human rights violations seem to be an everyday occurrence. Politics of the north east is very strongly associated with corruption ${ }^{\text {lii. }}$. External powers such as Chinaliii, Myanmar, Pakistan and Bangladesh have helped rebel groups in the past with weapons and military training. The situation here is very complex because there are many different layers of conflict ${ }^{\text {liv }}$. Insurgents themselves are very much divided. The main issue has been over self-determination and in some cases the achievement of complete independence from Indialv or at least more autonomy. The region has been seen as one of South Asia's 'most contested spaces'. Ivi For some of the other states, the main issue has been migration ${ }^{\text {lvii }}$ and the incoming of migrants from Bangladesh into the northeast of India" Iviii. Sanjib Baruah writes, 'Cross border migration and citizenship are highly controversial issues in Assam and the rest of Northeast India. For six long years, from 1079 to 1985, there was a powerful protest movement against the entry and enfranchisement of foreigners, mostly immigrants from former East Pakistan/Bangladesh. In India, this campaign is conventionally referred to as the Assam movement. There was significant opposition during this period to the holding of elections, and when they were held, they were marred by ethnic violence. ${ }^{\text {lix }}$ In Assam, there have also been protests because the centre has tried to exploit Assam's natural resources like oil. Paul Collier in his article, 'the ethics of natural assets', considers the spatial dimension of the ownership of natural assets, and asks the question: should they be owned by the people living nearest to where the natural assets are located, or should the benefits of these natural resources be shared with the rest of the country ${ }^{1 \mathrm{x}}$. In the Assamese case, the people of Assam clearly thought that their needs were being made subservient to the needs of the centre, and people living in India proper. They strongly felt that they should benefit from their own regional resources and natural assets. The political situation has been unstable for a while now and people are disillusioned with both central and regional political parties. Bhagat Oinam talks about how there is a growing disenchantment and cynicism with the political system due to the fragmentation of politics, the frequent change in party loyalties, the breakdown in governance etc. ${ }^{\mid x i}$ The insurgency has of course changed its identity and nature with time and in some areas like Mizoram, the situation has quietened down, and has been dealt with successfully by the Indian government. However, much remains to be done. There are still high levels of political violence in other parts of the northeast especially Assam, Manipur and Nagaland. Thus, it is very much a work in progress. Haokip writes, 'By the turn of the 1990's, India's north eastern region witnessed a proliferation of ethnic insurgent groups vying for different levels of autonomy, ranging from claims for autonomous district councils to redrawing of state boundaries to create new

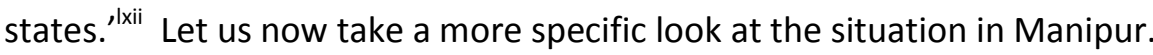

\section{THE SITUATION IN MANIPUR:}

I recently got the opportunity to carry out a few interviews with men of Manipuri origin and asked them about what they thought about the politics and insurgency of Manipur, and this is what they had to say about the situation :

'India as a nation is politically unstable. The frequent change of politicians and alterations in high level politics can have an adverse impact on regional politics. The change in high level politics tends to delay progress at the regional level. Whichever political party takes over at the centre, has had an impact on Manipur. With regard to the insurgency, there is a great deal of controversy. The insurgency started in the first place in Manipur because of the annexation of Manipur by India during the time of Vallabh Bhai Patel and Maharaj Bodha Chandra. Firstly, Manipur was given 
princely status, then it was considered a union territory and it was only in 1974 that Manipur attained statehood. The common people of Manipur were not favoured by the centre due to the political instability in the region, and it was in this context that the insurgency came into existence. When we look at the insurgency, it has gone through different phases. The common people like the poor farmers and labourers initially supported the insurgents, since the insurgents supported the poor people. People did not gain any material benefits due to political corruption. With time, however, Manipur did gain political stability, and once it gained political stability, the insurgents did not have much to do or much to fight for. Hence, at this stage, they changed or diverted their plans and aims. Now, the insurgents started demanding money from individuals and families, and even extracted wealth by force. For instance, they took away vehicles by force. The people started opposing them, and the government took positive steps in enforcing the police department of Manipur and the Army in the late nineteen nineties till about 2001/2002. It was from this time that the insurgents stopped mingling with the local people. The insurgents moved away from the cities. The insurgents now started recruiting new members and this gave rise to a new form of insurgency. Due to the mushrooming of new insurgent groups, there was a lot of fighting against each other and internal rivalry. The insurgency thus became characterised by factionalism. Insurgent leaders were fighting against each other for their own selfish needs and interests. The insurgency today is very much alive. Because of the Armed Forces Special Powers Act, there is a great deal of instability in the region. There are regular 'bandhs' or strikes and protest movements against the Armed Forces Special Powers Act. Transportation in the Indian Northeast has become a huge problem because the insurgents often charge tax and demand a huge amount of money from travellers. Tax is also charged when goods are being transported. Vehicles are often stopped and forcefully taxed. In this connection, mention maybe made of the 'gundagari charge', which is taken by north eastern insurgents for the transportation of goods in the north east. Manipur has always experienced major transportation problems due to the lack of good roads and railways. The two major highways are the Imphal-Silchor Highway and the Imphal-Gawhati Highway. The safest way to get to Manipur is by flying, and then one can easily avoid facing the insurgents. Economically, Manipur is struggling, and poverty and unemployment levels are very high. The influence of insurgents has been reduced in recent times, but some of the clauses associated with the Armed Forces Special Powers Act also need to be removed. The whole of the Act should not be removed as Manipur is a border state, and there are always lots of migrants coming from Myanmar and Bangladesh. The increase in population makes competition even fiercer. The army personnel are not very educated and they take advantage of the Armed Forces Special Powers Act. For the Indian Army, every local is an insurgent. Women have been involved in the insurgency and the raping of women is a regular practise by army personnel. Local people don't see the army as very friendly. The army does not mingle with the local people, although they will say that they are friends of the hill people. There should be more exchange of ideas between the local people and the Indian Army, so that the local people understand the duties of the army and so that the army has a better understanding of local Manipuri culture. In early 2000, in a place called Malom, ten people were killed by the army and none of these jawans/army personnel were punished or brought to justice. This was when Irom Sharmila, an activist from the region, started to protest, and went on hunger strike, since innocent people were being killed. The incident caused such outrage that there were numerous protests, bandhs and strikes after this, and the chaos went on for a year. This caused so much instability in the region that students lost one full academic year. With regard to the role played by neighbouring countries, there are rumours that Myanmar and China deliver weapons directly to insurgents to fight against the 
Indian Army especially in places like Sagitampak. Local Manipuri people cross the Indo-Burmese border on a daily basis just by paying a certain sum of money to the border security officials.'

Now, it seems to me that the information given to me by my first interviewee was by and large accurate, and it can be taken as the truth. This is because my interviewee was in a relaxed situation where he could talk freely. I interviewed him in Kolkata, and not anywhere in north eastern India, which is heavily militarised. He was free to talk, and express his views openly. There were no Assam Rifles security personnel patrolling the street where we were having this conversation, so there was no pressure on him. Although we were talking about very sensitive issues, we were far away from the north east, in the city of Kolkata in West Bengal. Furthermore, a lot of the information that he provided me with sits comfortably with the existing body of scholarly literature. For instance, he mentioned that many of these insurgent groups, to begin with, started waging war against the Indian state because they fought on behalf of the people of the region. It is well known in the existing body of scholarly literature on the north east that many insurgent groups like the ULFA/United Liberation Front of Assam and the NSCN/ National Socialist Council of Nagaland all had a socialist agenda to begin with. Another example is when he hinted at the factionalism and the rivalry which exists amongst the insurgents. This is also quite established in the literature on the north east. There was also no language problem between me and my interviewee. My first interviewee also mentioned that because of the on-going insurgency academia was continuously being disrupted, and that students were losing out years. This line of argument sits comfortably with what well known activist from Manipur, Bina Lakshmi Nepram had to say about the situation in Manipur, at the Indian of the Year Award at New Delhi in 2011.

I also managed to carry out another interview with two men of Manipuri origin and this is what they had to say about the situation in the region: They were interviewed together.

'Politics in Manipur is associated very strongly with corruption. People cannot choose the right leader because of this entrenched corruption. People have no real voters' rights. In Manipur, voters' rights are equal to money power. If one has money, one also has political power. It is difficult to get jobs in Manipur, which is why Manipuri people like us have to come to places like West Bengal or travel to other Indian states. To be able to work in Manipur, one has to pay MLA's/Member of the Legislative Assembly a lot of money. There is the presence of strong underground terrorist elements in Manipur. Some of them want to be in a separate country, and not be a part of India. There are about 30-40 such insurgent groups in the north east and in Manipur. In Manipur, of course all the insurgents are mixed up. In this connection, mention maybe made of the Kuki National Front, Kuki National Organisation and the United Liberation Front. These groups are still very active. The United Liberation Front thinks about winning independence for the motherland. The insurgents believe that the centre does not look after Manipur very well. The Indian Army and the Assam Rifles have taken advantage of the Armed Forces Special Powers Act. Raping of women has been a regular occurrence. The situation today, is of course better than what it used to be a few years ago. Weapons for the insurgents come through a town called Moreh, which is on the Indo-Burmese border. The insurgency is still very on-going, and the centre is required to look after Manipur better. '

Again, like my first interviewee, what these two men of Manipuri origin said to me can be taken as accurate and truthful since they were interviewed in Kolkata, in a relaxed environment. They weren't being monitored by the Assam Rifles or the Border Security Forces. They could freely 
express themselves. Furthermore, again like the first interviewee, a lot of the information that they gave me sits well with what is established in the literature and what other people from the north east have also told me about the current situation e.g. the issue of corruption.

\section{METHODS OF PEACE BUILDING:}

Needless to say that there is no easy solution to the problem or set of problems that we have identified and discussed so far. There are no right or wrong answers. There are certainly no straight forward answers. So far we have looked at some of the different facets of the conflict in the Indian northeast. This was necessary before coming up with any possible solution which might or might not work. It is of course firstly important to identify the causes of the conflict or the different facets of the conflict before we can come up with an answer or set of answers. As some analysts have argued, the right circumstances for successful de-escalation of violence in any conflict can be

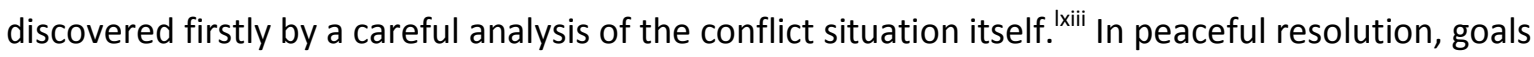
are to be pursued by means other than the use of threats and the use of force. In trying to manage ethnic tensions, the use of force or violence can be counterproductive and produce a backlash by generating further hostility and violence. We see this happening in Northeast India. The political elite in New Delhi have responded to borderland insurgency with repression. In this context mention must be made of the Armed Forces Special Powers Act which gives security personnel in the borders extraordinary powers to deal with the situation. The Armed Forces Special Powers Act has often been abused and misused by Indian security forces. Much of the militancy in the northeast is a response to the draconian Armed Forces Special Powers Act.

Depending on the nature and the sources of the conflict there are indeed many different ways of arriving at a range of answers or solutions to the conflict situation. Internal conflicts or civil wars are often the most difficult to manage. Constructing a road to peace has been a challenge for centuries for policy makers. ${ }^{\text {kiv }}$ A peace agreement however is no guarantee against further violence and many of these peace processes have often collapsed. In many instances, early promises have not been kept and even those that did manage to complete a peace agreement are still fraught with problems, peril and uncertainty ${ }^{\mathrm{Ixv}}$.

Peace building maybe defined as the effort to strengthen the prospects of peace and decrease the likelihood of violent conflicts. The overall aim of peace building is to 'enhance the indigenous capacity of any society to manage conflict without violence'. Ixvi Peace building has the goal of strengthening people's security, democratic governance, human rights, rule of law, civil society, sustainable development, equitable access to resources and environmental security. The whole process takes a long time and involves conflict prevention, conflict resolution as well as a diverse range of post conflict activities. This concept tends to focus more on the political and socioeconomic context of the conflict rather than laying emphasis on the military side of things. In terms of attaining a sustainable, long lasting peace it is important that external support for peace building should supplement or help local efforts and not substitute local efforts in achieving peace. The process can be arduous and protracted. There will be huge challenges particularly in the countries of the global south which have been facing armed conflict for decades. Peace builders should be able to create an atmosphere of socio-economic justice and political revitalisation, where poverty is reduced substantially and democratic institutions are created. It should be noted though that many of these ceasefires not only break down but can actually pave the way for more violence. ${ }^{\text {Ixvii }}$ The 
progress that is often made can be very slow and takes place step by step. Many of these peace processes involve long discussions and negotiations in which concessions are rare, and even when concessions are made from one side to another they ultimately do not work out when it reaches the stage of implementation. The number of people involved in the process has increased. 'The traditionally passive role of peacekeeping has been replaced by a more active role of peacekeeping involving national reconstruction, facilitating transition to a democracy and providing humanitarian assistance'. ${ }^{\text {lxviii }}$ As the nature of conflicts in the post-Cold War era has changed, so did the challenges to the peace keepers. Methods of peace keeping have changed with the passage of time depending on the nature of the challenge/conflict.

Contemporary peace operations include conflict prevention, conflict mitigation, peacemaking, peace-keeping, peace enforcement and also post conflict peace building. A notable feature of peacekeeping activities since the nineties has been the growing number of tasks associated with demobilisation and disarmament. These activities have included storing weapons, registering combatants etc. Peace keepers have also performed a whole range of tasks at the community/grassroots level. In this connection mention must be made of building roads, repairing roads and infrastructure such as water supplies, transportation systems, medical support etc. ${ }^{\text {lxix }} \mathrm{A}$ watchful eye must be kept on weapons and weapons control. However, withdrawal of troops from territory captured in war does not in any way guarantee peace but the failure to withdraw is quite likely to bring another round of fighting. ${ }^{1 \times x}$ Arms control can to some extent minimise the risk of military tension but arms control in itself cannot be effective to maintain peace, stability and security. Controlling arms in this part of India might prove to be a challenge since a lot of the arms come from across the Myanmar border and are smuggled into India. Furthermore, the northeast is also heavily militarised with a strong presence of the Indian Army, the Border Security Force, the Central Reserve Police Force and the Assam Rifles. Because of the heavy presence of security personnel, there is easy access to weapons.

However, what is more of an issue in the conflicts in the Indian northeast is the problem of social exclusion. Acts of terrorism in the northeast have arisen due to feelings of alienation and marginalisation. Marginalisation refers to both social and economic marginalisation. For instance, people in the north east feel left out from the economic success that India proper is currently experiencing. The impressive growth rate which the country has experienced since the mid 90's has not had a positive impact or trickle down impact on the people of the northeast. The region even today is by and large impoverished. The people of India proper seem to know more about the United States of America than the north eastern part of their own country. Therefore, governments at both the regional level and at the national level will need to design policies that attack exclusionary practices and approaches to make sure that minorities in the borderlands do not feel excluded, but feel more included in the national framework. The isolation can decrease to some extent through India's Look East and Act East policy. As India develops strong linkages with other countries of East Asia, the people of the northeast are likely to feel more embraced because the only way India can facilitate or strengthen its connections with East Asia is through the northeast. As connectivity and infrastructure develops and increases to help this relationship between India and other East Asian countries, the people of the north east are likely to benefit from this process as well ${ }^{1 \times x i}$.

First of all, there has to be a careful analysis of all the issues involved and the parties. Secondly, these parties whose relationships have been strained need to be brought to the 
negotiating table to be able to interact with one another. This will help the parties to discuss their current estranged relationship in great detail. With the passage of time, other issues and concerned parties are also brought into the discussion. At this stage, discussions take place but no bargaining or real negotiating takes place. Once a clear assessment has been made of the entire situation and everyone's voices and grievances heard, then only can we proceed to the next stage of exploring all the possible positive options, after there has been an agreed definition of the problem. However, identifying the problem can be very challenging in the Indian north east, because the nature of the problem is very complex.

In the on-going conflicts of the Indian north east, it is extremely important for the concerned parties to engage in constructive dialogue. Communication is very important and effective communication can relieve the tension to some extent. Resolving one conflict, however, does not prevent the next one $e^{1 \times x i i}$. Conflict resolution is not just about preventing acts of violence to happen but is also concerned with improving the general conditions of a particular area and creating a situation which will create cooperative relationships between the once disgruntled parties. In this connection, mention maybe made of non-governmental organisations such as the 'Conciliation Resources' group based in London, which is involved in conflict zones around the world. Conciliation resources, believes that those living in the midst of the conflict have the greatest insight into its causes and resolution ${ }^{1 \times x i i i}$. The group is especially concerned with cross border peace building, and believes that armed groups need to be involved in the whole process.' Conciliation resources' also believes that poor governance can often be the root cause for a conflict and this can be exacerbated by the presence of weak institutions. It also believes that both politicians and policy makers should be joining hands together and working together towards the resolution of a particular conflict and that opportunities for discussion between the disputants need to be created.

Peace processes or conflict resolution are often carried out in specific stages. Scholars and analysts have spoken about the first stage which is often called pre negotiation which may involve secret talks. This is the process when the terms of disengagement from violence and engagement in negotiations are agreed upon ${ }^{\text {Ixxiv }}$. After this, we see the formal ending of violence, usually through ceasefires. Then we see the actual process of negotiation happening and finally the process of reconstruction or post settlement peace building. Violence may affect these different phases in different ways and the negotiation process itself may often be accompanied by the emergence of more dissident groups. 'Negotiators also have to confront a new range of priority issues including demands for the early release of prisoners, demobilisation and disarmament and policing reform, as well as the re integration of militants into society and consideration of their victims.' Conflict resolution or a peace process may generally follow the above stages but there may be local differences depending on the region, where the conflict is taking place.

Mediation is a term often used in the conflict resolution literature. Mediation in a dispute is basically defined as the intervention of a third party that is not familiar with the intricacies of the conflict and therefore can be trusted, is reliable, unbiased and neutral ${ }^{\mid \times x v}$. If one is a mediator, one needs to be extremely skilful and diplomatic. These skills are required to be able to bring the disputants to the negotiating table to come to some sort of an agreement on the issues of the dispute. The task of a mediator 'is creating the conditions for an open dialogue and assuring the parties involved in the conflict freedom of speech and above all autonomy in the decision making process'. ${ }^{\prime} \times x v i$ The mediator can therefore be seen as a facilitator, educator or communicator who 
helps to clarify issues. He/she is able to manage emotions and create opportunities, thus paving the way for an atmosphere of trust, amity and agreement. In other words, the purpose of having a mediator is to solve the issue at hand amicably, to avoid further internecine or mutually destructive warfare. Key elements to the whole process include trust and persuasiveness. The goals of mediation included the following :

- To develop trust and cooperation between the disputed parties.

- To develop and improve communication between the disputed parties.

- To assure the disputed parties that their perspectives and their version of events would be heard.

- $\quad$ To reduce tension and conflict.

- $\quad$ To help the disputed parties appreciate relevant information in order to make decisions based on proper data, after having considered alternative proposals to solve some of the issues.

- To favour confidentiality.

- $\quad$ And finally, to reach a reasonable and fair agreement.

Peace agreements are an integral part of conflict resolution and in some ways could be seen as a starting point for conflict resolution. However, peace requires more than just an agreement among the disputed parties. 'Conflict resolution can be defined as a situation where the conflicting parties enter into an agreement that solves their central incompatibilities, accept each other's continued existence as parties and cease all violent action against each other. . $^{\prime \prime x v i i}$ Conflict resolution and peace are not necessarily identical with each other although there is a good deal of overlap between the two. Very key to the whole process of conflict resolution is disarmament and demilitarisation. Demilitarisation is absolutely obligatory for ending an internal conflict. During the period after an internal conflict, the atmosphere is often fraught with peril and uncertainty. There are plenty of weapons all around, which are easily available, and there may be much anger and frustration in the atmosphere, which needs to be diffused ${ }^{\mid \mathrm{lxv} v i i}$. In this climate, there is always the threat of war and conflict being resumed. Thus, it becomes important for the military to be a part of a new set up.

Another key component for conflict resolution is democratisation. Internal or domestic conflicts are often a struggle for power and the side which is being wronged wants its voice to be heard. This is very much the case in the Indian northeast. Thus the process of democratisation would involve having a multiparty system, access to the media, protection of fundamental rights, having the required security for election campaigns, having independent election commissions, an independent judiciary, fair elections and the free forming of new governments on the basis of election outcome. This is very important with regard to the Indian northeast because there are numerous parties involved in the conflicts. However, it would be naïve to suggest that democratisation would succeed in neutralising ethnic separatism ${ }^{1 \times x i x}$. 'The success of the democratic experiment in defusing ethnic tensions will depend on a number of factors such as the speed with which ethnic tensions/issues are recognised, the level of ethnic tension when the process of democratisation begins, the size and power of different ethnic groups within the state, the ethnic 
composition of the previous regime and its opposition, the political position of the leaders of the main ethnic groups, the presence or absence of external ethnic allies, and finally the ethnic composition of the military. ${ }^{, 1 \times x x}$

Peter Wallensteen, argues that there are seven distinct ways in which disputed parties can coexist and 'dissolve their incompatibility' ' $^{\prime x x i}$. The seven ways identified by Wallensteen are:

- A party may change its goals or shift its priorities.

- $\quad$ The disputed parties can stick to their aims, goals and agenda but figure out a way by which resources can be equally or at least reasonably divided by the disputants.

- Horse trading is a way by which one side has all of its demands met on one issue, while the other has all of its goals met on another issue.

- One way of reaching a middle path could be if the disputed parties came to share control over existing resources and also share political power. In this situation, both the parties decide to rule together over the disputed resource.

- A fifth way of maintaining some element of peace, security and stability is to leave control to somebody else, which means externalising control, so the warring parties agree not to rule the resources themselves. In this connection, special mention maybe made of the mediator and the effective role played by the mediator in resolving the problem.

- There is always the possibility of making use of the services of conflict resolution mechanisms, especially arbitration or other legal procedures which the parties may be willing to accept.

- $\quad$ Finally, the issues which the conflict revolves around could be left for later, although this does not do much in actually reducing the existing tension.

\section{PEACE BUILDING AND NORTH EAST INDIA:}

Before coming up with peace building measures which would work specifically for north eastern India, one first of all really needs to appreciate how the identity, colour and nature of the conflict has changed with the passage of time. This applies to all the conflicts in the north eastern region. Dolly Kikon in a 2005 article notes the 'changing phases' of Naga nationalism, and the 'several shifts', it has gone through ${ }^{1 \times x \times i i}$. Bethany Lacina argues that 'the changing patterns of violence in the north east call for a re-examination of the likely efficacy of security and political interventions that are aimed at quelling a rural insurgency with a grassroots base. ${ }^{\prime 1 \times x x i i i}$ She further argues that 'interventions that are designed to undermine insurgencies organised in a conventional sense will not remove the enabling conditions of these very different patterns of violence ${ }^{\prime \mid x x i v}$. On most occasions, when the insurgency has flared up, the Indian government has responded with 
repressive measures. Kham Khan Suan Hausing writes, 'As the Naga independentists adopted armed struggle to realise their nationalist aspirations, the Indian state swiftly responded with coercion and cooption $^{\prime \mid x \times x v}$. It is of course very difficult to come up with a solution or even a set of solutions to the problem/set of problems which we have discussed in this paper. However, here are a few suggestions:

Firstly, demilitarisation in the region would help the situation to some extent, but it is doubtful whether or not the Indian establishment would allow this to happen, since the region is classified as a 'disturbed area'. The region is not only heavily militarised, but the security personnel have extraordinary powers which they often abuse. Civil rights violations seem to be an everyday occurrence, which adds to the conflict. The security forces have been responsible for all sorts of civil rights violations, and human rights violations. For instance, the rape cases in the region are very high, committed mainly by men associated with the Indian Army and paramilitary forces. Sajal Nag and Tejimala Nag writes, 'While the Indian army's operation in insurgency-affected areas has never been known for its restraint, in recent times the ferocity and frequency of the army's human rights violations is on the increase. ${ }^{\prime \prime x x v v i}$ Laws like the Armed Forces Special Powers Act have only made things worse. Whilst it is understood that stationing security forces in a border region is essential to protect the country from external attacks, it is equally important for there to be checks on what the military personnel can and cannot do. In many ways, the security forces are causing the problem on a day to day basis. There needs to be more accountability. These forces need to be educated before they are stationed in the region and training needs to be given in such a way so that these security personnel are respectful and sensitive towards local customs, practices and culture. If the Indian establishment cannot or is not willing to lessen its security forces in the region, then at least there needs to be more monitoring of the actions of these forces. The policing of the actions of security personnel needs to take place from a higher authority. These security forces should be made accountable to such an authority. Because many of these military men feel that they are above the law, and that they are not accountable to any higher overarching authority, they have often taken the law into their own hands and misused it. It should be also noted though that it is not just the security personnel who cause havoc in the region. The insurgents, their factional groups and other self-styled rebels have also been continuously causing mayhem, which is still very much the case today. As some of my interviewees mentioned the insurgent groups harass people for money, and keep on making higher demands for money from people.

Secondly, the major disputants need to be brought to the negotiating table. This will obviously be a very challenging job, since there are so many insurgents and underground elements involved in the conflict/conflicts. There are many different layers of the conflict in Manipur and elsewhere in the northeast, and hence identifying disputants becomes quite a challenging task. Also, if it is possible to ever bring the different disputants to the negotiating table, these meetings will need to be supervised by an impartial authoritative figure. In this connection, world organisations and their specialised agencies or regional organisations from other parts of the Asia Pacific could play a crucial role. 
Thirdly, issues like corruption, poor governance, administrative failure, poverty, unemployment and lack of infrastructure which are part of the problem need to be looked into. This needs to be looked into very urgently. Streamlining the bureaucracies could help the corruption issue to some extent. Money channelled from the centre would need to go into the hands of the right ministers associated with finance. Instead of spending so much money on arms and weapons, the Indian establishment would need to think about careful channelling of money which could help with infrastructure development. Only by looking into these areas, can we hope to have long lasting peace in the north eastern states of India.

Fourthly, since it is believed that insurgents get their weapons from across the Indo-Burmese border, especially through towns like Moreh, strict patrolling of this region would be helpful. Border security officials should also be paid high salaries so that they don't accept bribes from people who want to cross the border from either side.

To end on a more positive note, 'the regional economic integration policy of India with its eastern neighbours, which has been implemented in the form of the Look East Policy and the softening of national borders, can reduce the marginalisation and alienation of the people of Northeast Indiaalxxvii . With better international relations especially economic relations between India and India's eastern neighbours in the Asia Pacific region, one can expect a gradual demilitarisation to take place in the region in the years to come. Bimol Akoijam, also writes, that thanks to the economic boom which many south east Asian nations have been experiencing since the nineties and the need to look eastward, the north eastern states of India are likely to get more attention in the years to come from the 'mainstream national consciousness' isolation are likely to come to an end, as the Indian economy gets more and more integrated into the economies of the Asia Pacific region. Countries like Singapore and South Korea have recently shown a lot of interest in India and India's economy. China since 2000 has been hugely involved in developing India's infrastructure, and hence the concept of 'Chindia', which refers to two separate but integrated economies. Under the current Narendra Modi leadership, ties with Japan are also likely to strengthen in the years to come. 
'R.Bhargava, 'What is Indian Secularism and What is it for?', India Review, 1(1), 2007, p1.

ii A.Roshwald, The Endurance of Nationalism, Cambridge University Press, Cambridge, 2006, p1.

iii R.H. Wiebe, Who We Are: A History of Popular Nationalism, Princeton University Press, New Jersey, 2002, p5.

iv J.Breuilly, 'The State and Nationalism', in M.Guibernau and J.Hutchinson, eds, Understanding Nationalism, Polity, Cambridge, 2001, p32.

$\checkmark$ J.Breuilly, Nationalism and the State, Manchester University Press, Manchester, 1993, p2.

${ }^{v i}$ N.Y.Davis, The Politics of Belonging, Sage Publications, Los Angeles, London, New Delhi, 2011, p94.

vii M.Guibernau, The Identity of Nations, Polity Press, Cambridge, 2007, p1.

viii Ibid.

ix Ibid, p11.

${ }^{x}$ S.Nag, 'Nehru and the Nagas: Minority Nationalism and the Post-Colonial State', Economic and Political Weekly, Vol XLIV, no 49, $5^{\text {th }}$ December, 2009, p52.

${ }^{x i}$ K.Bajpai, Roots of terrorism, Penguin Books, New Delhi, 2002.

xii J.D.Fearon, 'Separatist Wars, Partition and World Order', Security Studies, 13(4), 2004, p395.

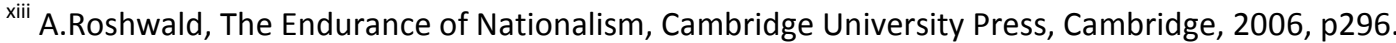

${ }^{\text {xiv }}$ A.Khan, Politics of Identity, Sage Publications, New Delhi/London, 2005, p29.

${ }^{x v}$ Ibid.

${ }^{x v i}$ A.Misra, The Politics of Civil Wars: Conflict, Intervention and Resolution, Routledge, London/New York, 2008, pp7-8.

xvii B.Lacina, 'Explaining the Severity of Civil Wars', Journal of Conflict Resolution, 50(2), April, 2006, p287.

xviii B.Harff and T.R.Gurr, Ethnic Conflict in World Politics, Westview Press, Boulder, Colorado, 2004, p1.

${ }^{x i x}$ J.Rudolph, Politics and Ethnicity: A Comparative Study, Palgrave, Macmillan, Basingstoke, New York, 2006, p1.

${ }^{x x}$ T.HEriksen, Ethnicity and Nationalism, Pluto Press, London, Sterling, 1993, p4.

xxi Ibid.

xxii S.Nag, 'Nehru and the Nagas: Minority Nationalism and the Post-Colonial State', Economic and Political Weekly, Vol XLIV, No 49, $5^{\text {th }}$ December, 2009, p52.

xxiii Ibid.

${ }^{x x i v}$ B.Oinam, 'Patterns of Ethnic Conflict in the North East', Economic and Political Weekly, May 24, 2003, p2033.

${ }^{x \times v}$ A.D.Smith and J.Hutchinson, eds, Ethnicity, Oxford University Press, Oxford, 1996, p13.

xxvi Ibid.

xxvii S.Wolff, Ethnic Conflict: A Global Perspective, Oxford University Press, 2006, p10.

xxviii Ibid.

${ }^{x x i x}$ M.E.Brown, Ethnic Conflict and International Security, Princeton University Press, Princeton, New Jersey, 1993, p5.

${ }^{\mathrm{x} x}$ Participant Observation, Fieldtrip to Manipur, January, 2014.

${ }^{x x x i}$ A.B.Akoijam, 'Manipur: How History Repeats Itself', Economic and Political Weekly, 28 ${ }^{\text {th }}$ July, 2001, p2812.

xxxii U.A.Shimray, 'Linguistic Matrix in Manipur', Economic and Political Weekly, $19^{\text {th }}$ August, 2000, p3007.

xxxiii K.Bajpai, Roots of Terrorism, Penguin Books, New Delhi, 2002.

${ }^{x x x i v}$ N.Kipgen, 'Politics of Ethnic Conflict in Manipur', South Asia Research, 33(1), p21.

${ }^{x x x v}$ M.E.Brown, p5.

xxxvi Ibid, p15. 
xxxvii A.Heraclides, The Self Determination of Minorities in International Politics, Frank Cass, London, $1991, \mathrm{p} 1$. xxxviii B.Harff and T.R.Gurr, Ethnic Conflict in World Politics, Westview Press, Boulder, Colorado, 2004, p1.

xxxix Ibid, p4.

${ }^{x l}$ N.Dholabhai, 'Nido Panel for more debate on Racism Law', The Telegraph, Calcutta, Thursday, $17^{\text {th }}$ July, 2014 and Special Correspondent, 'Northeast Fatality in Capital Again', The telegraph, Calcutta, $22^{\text {nd }}$ July, 2014.

xli Interviews carried out in Kolkata, 2013/2014.

xlii U.A.Shimray, 'Socio-political unrest in the region called North East India', Economic and Political Weekly, $16^{\text {th }}$ October, 2004, p4637.

xliii B.Lacina, 'The Problem of Political Stability in Northeast India: Local Ethnic Autocracy and the Rule of Law', Asian Survey, 49(6), 2009, p1000.

xliv N.Farelly, 'K47/M16 Rifle-Rs.15, 000 Each: What price peace on the Indo Burmese border?' Contemporary South Asia, 17(3), 2009, p284.

${ }^{x l v}$ N.Haksar, Across the Chicken's Neck: Travels in North East India, Rainlight Publishers, New Delhi, 2013.

xlvi T.Myint-U, Where China Meets India: Burma and the New Crossroads of Asia, Faber and Faber, London, $2011, \mathrm{p} 272$.

xlvii S.Dutta, 'Northeast Turmoil: Vital Determinants', Strategic Analysis, 23(12), 2000, p2123.

xlviii C.Singh, North East India: Politics and Insurgency, Manas Publications, New Delhi, 2007, p9.

${ }^{x l i x}$ B.Lintner, Great Game East: India, China and the Struggle for Asia's Most Volatile Frontier, Harper Collins, New Delhi, 2012, p136.

'J.Glancey, Nagaland: A Journey to India's Forgotten Frontier, Faber and Faber, London, 2011, p1.

li R.K.Nanavatty, Internal Armed Conflict in India: Forging a Civil Military Approach, Centre for Land Warfare Studies, Pentagon Press, New Delhi, 2013, p40.

lii E.N.Rammohan, 'Corruption and Insurgency in the Northeast', in K.S.Subramanian, ed, Security, Governance and Democratic Rights: Essays on the Northeast, Niyogi Books, New Delhi, 2014, pp85-89.

liii S. Hazarika, Strangers of the Mist: Tales of War and Peace from India's Northeast, Penguin Books, New Delhi, 2011, pp103-105.

liv K.Mukherjee,'The Conflict in the Indian Northeast', Defence Studies: Journal of Military and Strategic Studies, 14(2), June, 2014, p112.

Iv N.Goswami, 'Making sense of Insurgencies in North East India: An Overview', in S.Dutt and A.Bansal, eds, South Asian Security:21 $1^{\text {st }}$ Century Discourses, Routledge, London/New York, 2012, p180.

Ivi D.McDuie-Ra, 'Fifty Year Disturbance: the Armed Forces Special Powers Act and the Exceptionalism in a South Asian Periphery', Contemporary South Asia, 17(3), 2009, p255.

Ivii S.Hazarika, Rites of Passage: Border Crossings, Imagined Homelands, India's East and Bangladesh, Penguin Books, New Delhi, 2000.

lviii S.Hazarika, Writing on the Wall: Reflections on the Northeast, Penguin Books, New Delhi, 2008, pp129-144.

${ }^{l i x}$ S.Baruah, 'The Partition's Long Shadow: the ambiguities of citizenship in Assam, India, Citizenship Studies, 13(6), December,2009, p593.

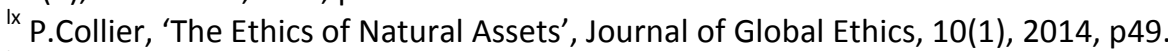

Ixi B.Oinam, 'Manipur, Assembly Election: Manifestation of Growing Crisis', Economic and Political Weekly, $6^{\text {th }}$ July, 2002, p2683.

Ixii T.Haokip, 'The Kuki-Naga Conflict in the light of recent publications', South Asia Research, 33(1), 2013, p78.

Ixiii H.Jeong, Conflict Management and Resolution: An Introduction, Routledge, London/New York, 2010, p21.

${ }^{\text {Ixiv }}$ C.A.Crocker, Managing Global Chaos: Sources of and Responses to International Conflict, United States Institute of Peace Press, Washington D.C, 1996.

Ixv J.Darby, eds, Violence and Reconstruction, University of Notredam Press, Notre Dame, Indiana, 2006, p1.

Ixvi N.Ball, 'The Reconstuction and Transformation of War Torn Societies and State Institutions: How Can

External Actors Contribute?' in T.Debiel and A.Klein, eds, Fragile Peace: State Failure, Violence and

Development in Crisis Regions, Zed Books, New York, London in association with The Development and Peace Foundation, Bonn, 2002, p35.

Ixvii E.Newman and O.Richmond, eds, Challenges to Peace Building, United Nations University Press, New York, Tokyo, 2006, p1.

Ixviii R.Murphy and K.Manson, eds, Peace Operations and Human Rights, Routledge, London/New York, 2008.

Ixix M.R.Berdal, Disarmament and Demobilisation after Civil Wars: Arms, Soldiers, and the Termination of Armed Conflicts, Oxford University Press, Adelphi Paper, 303, The International Institute for Strategic Studies, 1996, p59. 
${ }^{\text {Ixx }}$ V.P.Fortna, Peace Time: Ceasefire Agreements and the Durability of Peace, Princeton University Press, New Jersey, Princeton and Oxford, 2004, p209.

${ }^{\text {Ixxi }}$ K.Mukherjee, 'The Conflict in the Indian Northeast, Defence Studies, 14(2), 2014, pp111-133 and

K.Mukherjee, 'India's Fractured North eastern Frontier: An Overview', Asia Pacific Review, 21(2), 2014, pp149-

170.

Ixxii D.J.D.Sandhole and H.V.D.Merwe, eds, Conflict Resolution: Theory and Practise, Integration and Application, Manchester University Press, MUP, Manchester, New York, 1993, p60.

Ixxiii www.c-r.org

Ixxiv J.Darby, ed, Violence and Reconstruction, University of Notre Dame Press, Notre Dame, Indiana, 2006, p3.

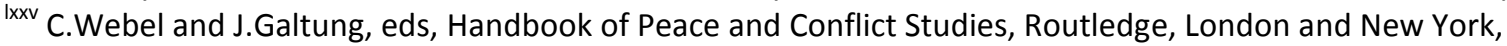
2007, p51.

Ixxvi Ibid.

Ixxvii P.Wallensteen, Understanding Conflict Resolution, Sage Publications, London, New Delhi, Thousand Oaks, 2002, p8.

Ixxviii Ibid, p142

Ixxix M.Ayoob, 'State Making, State Breaking and State Failure', in C.Crocker, eds, Managing Global Chaos:

Sources of and Responses to International Conflict, United States Institution of Peace Press, Washington D.C., 1996, pp46-47.

Ixxx Ibid.

Ixxxi P.Wallensteen, Understanding Conflict Resolution, Sage Publications, London, New Delhi, Thousand Oaks, 2002, pp54-57.

Ixxxii D.Kikon, 'Engaging Naga Nationalism: Can Democracy Function in Militarised Societies?', Economic and Political Weekly, $25^{\text {th }}$ June, 2005, p2833.

Ixxxiii B.Lacina, 'Does Counter Insurgency Theory Apply to Northeast India?', India Review, 6(3), 2007, p165. Ixxxiv Ibid.

Ixxxv K.K.S.Hausing, 'Asymmetric Federalism and the Question of Democratic Justice in Northeast India', India Review, 13(2), 2014, p95.

Ixxxvi S.Nag and T.Nag, 'Human Rights Violations in Naga Hills', Economic and Political Weekly, $8^{\text {th }}$ April, 1995, p738.

Ixxxvii T.Haokip, 'Recent Trends in Regional Integration and the Indian Experience', International Area Studies Review, 15(4), 2012, p390.

Ixxxviii A.B.Akoijam, 'Manipur: How History Repeats Itself', Economic and Political Weekly, 28 ${ }^{\text {th }}$ July, 2001, p2807. 